\title{
Needs Analysis for the Development of a Training Module for Hypercontent Examination Emission Inspection at the Ministry of Transportation
}

\section{Galuh Indri Kusumawati ${ }^{*}$, Murti Kusuma Wirasti ${ }^{2}$, Dwi Kusumawardani ${ }^{3}$}

1,2,3 Postgraduate Educational Technology, State University of Jakarta, East Jakarta, Indonesia

A R T I C L E I N F O

Article history:

Received 20 August

2020

Received in revised

Form 24 September

2020

Accepted 15 October

2020

Available online 01

November 2020

Keywords:

Needs Analysis,

Hypercontent Module,

Emission.

\begin{abstract}
A B S T R A C T
The main factor of air pollution in Indonesia is motorized vehicles. Motorized vehicles operating on the road will produce exhaust gas emissions which result in air pollution. In overcoming exhaust gas emissions in vehicles, the Ministry of Transportation conducts training for exhaust emission inspection, and conducts training at one of the technical implementation units, namely the Indonesian Land Transportation Polytechnic (PTDI) STTD. The purpose of this study was to conduct a needs analysis to develop a hyper content learning module for training on exhaust emission examinations, using the R\&D (research and Development) method using the Derek Rowntree model. The hyper content module is a module that combines hypertext, hyperlinks, and hypermedia, and the media used in the form of video, QR code, YouTube, and cloud computing. With the development of the hyper content module, it is possible to improve the understanding and learning outcomes of training participants in studying exhaust emissions from vehicles when compared to conventional learning.
\end{abstract}

\section{Introduction}

The transportation sector has become a major factor in the occurrence of air pollution in Indonesia. The consumptive nature of the Indonesian people has made the number of motorized vehicles in Indonesia increase, resulting in air pollution. Air pollutants are caused by the main factor is the result of motorized vehicle exhaust gases which each year increase rapidly based on data from the Central Statistics Agency (BPS), data is obtained that from 2013 to 2017 the increase in the number of vehicles in Indonesia increased by around $7.41 \%$ per year (Gunawan, et al., 2020).

Emissions are an important source of air pollution in cities (Huang et al., 2016). To control vehicle emission levels, motor vehicle emission measurements are carried out (Hakim et al., 2018). According to data from the Environmental Protection Agency (EPA) 44\% of hydrocarbons that reduce air quality in the atmosphere are produced from the transportation sector (Cetin, 2015). The influence of public policies on urban pollution (Borck, 2019). Reducing $\mathrm{CO}^{2}$ emissions that have an impact on global warming cannot only be monitored by local governments but must involve related agencies / institutions, producers, communities and other related parties who take part in road transportation (Nurdjanah, 2015). Vehicle exhaust emissions are influenced by vehicle age, vehicle maintenance, and engine capacity (Muziansyah, 2015).

In the Regulation of the Minister of Transportation of the Republic of Indonesia Number PM 63 of 2018 concerning Amendments to the Regulation of the Minister of Transportation Number KM 84 of 2009 concerning Procedures for Providing Education and Training Assistance and Scholarships in the Transportation Sector. Article 21A states that the implementation of the provision of education and training and educational scholarships can be in the form of a Community Empowerment Nursery and Education and Training Pattern (DPM), DPM is implemented with the aim of improving safety and security in the transportation sector, increasing the competence of human resources in the field of transportation, improving related public services. with transportation, and / or improve skills and knowledge for the community to make it easier to get a job in the transportation sector. Exhaust gas emission inspection 
training held by the Technical Implementation Unit (UPT) in the BPSDM Transportation Environment, one of which the UPT is the Indonesian Land Transportation Police (PTDI) STTD.

PTDI STTD, which is located in Bekasi, is one of the agencies that conducts training on exhaust emission inspection in collaboration with the Regency / City Transportation Agency, Land Transportation Management Hall (BPTD) employees, the general public and students throughout Indonesia. Training participants come from employees of the Regency / City Transportation Service, Land Transportation Management Hall (BPTD) employees, the general public, and students. By holding the implementation of this training, it is hoped that it can increase knowledge about exhaust gas emissions and applicable laws and regulations and can apply the knowledge gained in everyday life. PTDI STTD educates various kinds of training programs consisting of public service agency training, community empowerment training, technical training, and initial training. This study provides a limitation in the implementation of training that involves training participants who come from the District / City Transportation Agency employees.

With the characteristics of training participants from employees of the Regency / City Transportation Office with an age range ranging from 17 to 45 years and different levels of education. So according to Miarso (2016) to overcome the limitations of experience possessed by students, teaching media / teaching materials are needed. Teaching media / teaching materials also provide opportunities for learners to learn independently, at a place and time and at a speed that can be determined by themselves (Miarso, 2016). The role of the teacher in the Independent Instructional System (SPM) is as a facilitator, while learners learn independently using instructional materials specifically designed by training organizers (Atwi, 2014).

One of the training programs carried out is training on exhaust gas emissions. This training is a training that generally provides competence to training participants. By following the training, it is hoped that you can master the competencies that must be achieved. Examination of exhaust emissions is one of the skills training courses that are taught in the implementation of basic land transportation training, because the implementation consists of the delivery of material and field practice. In the implementation of the training, there are several aspects that are conveyed to the participants, namely aspects of knowledge, skills and attitudes. Allocation of training time which is carried out for 3 (three) days to deliver all material both theory and practice, but the training time provided is still insufficient.

Seeing the importance of implementing this training, it is necessary to have media assistance that can overcome problems in the learning process that occurs. Develop learning resources as a learning medium that suits your needs. Development (by design) and utilization (by utilization) of learning resources is one of the fields of work on educational technology, as in the definition of Educational Technology put forward by AECT. Educational technology is the study and ethical practice of facilitating learning and improving performance by creating, using and managing appropriate and appropriate technological resource processes. Based on this definition, it can be explained that educational technology is an ethical study and practice that aims to facilitate learning so as to facilitate the learning process, one of which is by creating learning media in the form of modules. According to (Purwanto, 2007) modules are learning materials that are systematically designed based on a certain curriculum and are packaged into the smallest learning unit and allow them to be studied independently in a certain time unit. Meanwhile, (Smaldino, Lowther, and Russell, 2012) state that the teaching module is a complete teaching unit designed to be used by a student or a small group of learners without the presence of a teacher. The purpose of this module is to facilitate learning without regular supervision, all elements of the subject given by the teacher usually have to be formed into a collection of printed, audiovisual, or computer-based material. Modules are learning resources that are arranged systematically, can be used for independent learning purposes and training participants can evaluate themselves through the exercises and questions contained therein to find out the extent of understanding of the material that has been studied. Print learning materials are also can improve student learning outcomes (Siang, Nurdin Ibrahim, \& Rusmono, 2017).

The results of the research conducted by (Situmorang et al., 2019) show that there is a significant increase in the cognitive abilities of the Teacher's Guide after using learning materials that are developed effectively and consultatively to fulfill the learning objectives based on QR Code. Research conducted by (Zhao and J. Qin, 2017) provides evidence that hyperlinks can enhance learning. Meanwhile, participants who are used to using ICT will find it easier in the online learning process (Siddiquah \& Salim, 2017). In research (Nasir \& Bargstädt, 2017) found that video tutorials not only transfer knowledge to the audience but also motivate them to learn. Modules equipped with videos will be more effective, efficient, attractive and productive in providing positive learning (Kusumaningsih, Nadiroh, \& Ibrahim, 2019). Learning by watching videos has become the dominant millennial way of learning. As is the case with research conducted by (Unless et al., 2016) that the videos used in the study are videos from YouTube. Currently, many videos can be accessed for free via YouTube. 
Cloud computing is a computing paradigm that has revolutionized the way computer infrastructure and services are provided. From the research (Sabi, Uzoka, Langmia, \& Njeh, 2016) conducted that cloud computing contributes to the academic literature as well as empirical evidence from the study results.From the explanation above that QR Code, YouTube, learning videos, cloud computing, are good for learning that can be delivered using hypercontent. This study aims to conduct a needs analysis to develop a hypercontent learning module for training on exhaust emission examinations.

\section{Methods}

This research is research and development or often referred to as Research and Development (R\&D). The model used in this research is a product-oriented development model, namely the Rowntree model. According to Rowntree, in developing teaching materials, there are three stages, namely the planning stage, the writing preparation stage, and the writing and editing stages (Rowntree, 1994). This development model was chosen because the product being developed is a hypercontent-based print module, a development model suitable for developing a hypercontent print module is a Rowntree development model. The development with the Rowntree model has three stages, namely the planning stage; Writing Preparation Stage; Writing and Editing Stage.

Data collection was carried out in the following ways observation to see the problems, conditions and characteristics of the participants; interviews with training participants, by asking various questions. This interview was conducted in order to obtain data about the implementation of learning in the class, documentation study, data obtained through documentation study includes data on curriculum, syllabus. The data needed in this research are qualitative and quantitative data. Qualitative data were obtained from interviews and observations. (Sugiyono, 2012), citing Miles and Huberman (1984) suggests that activities at the qualitative data analysis stage consist of data collection, data reduction, data presentation, and data conclusion. Meanwhile, quantitative data were obtained through questionnaires by material experts, instructional design experts, media experts, and participants.

\section{Result and Discussion}

\section{Result}

Needs analysis was carried out in preliminary research. The results of the observations obtained information on the characteristics of the participants in the exhaust emission inspection training, namely participants in the training in examining exhaust gas emissions have a heterogeneous and varied educational background, from high school graduates / equivalent to tertiary education, which were obtained from participant registration documents; the profession of training participants is an employee of the Transportation Service; the age of the trainees is heterogeneous from the age of 22 years to the maximum age of 45 years. Data distribution of the characteristics of participants in the 2019 exhaust emission inspection training organized by the Bekasi Polytechnic of Land Transportation with a total of 580 participants, which can be seen in the Table 1.

Table 1. Background Distribution of Participants in the 2019 Examination of Gas Emissions

\begin{tabular}{llcccccc}
\hline No & Training Program & \multicolumn{5}{c}{ Category Background } \\
\cline { 3 - 7 } & & \multicolumn{2}{c}{ General public } & \multicolumn{2}{c}{ SMK } & \multicolumn{2}{c}{ ASN } \\
\cline { 3 - 7 } & & $\mathbf{L}$ & $\mathbf{P}$ & $\mathbf{L}$ & $\mathbf{P}$ & $\mathbf{L}$ & $\mathbf{P}$ \\
\hline 1 & Exhaust Emission Inspection & - & - & $\mathbf{6 0}$ & - & 440 & 80 \\
\hline
\end{tabular}

\section{Discussion}

Adult students learn for the benefit of work and professions which they consider important for career sustainability as well as the future of their family (Prawiradilaga, 2016). Apart from the four aspects, namely aspects of independence, experience, readiness to learn and learning orientation, there are also obstacles, namely gaps in digital technology or digital video. Observations were also carried out to identify instructional needs, namely observing the facilities (curriculum, syllabus, media, teaching tools) and reports on the implementation of the training that had been carried out so far.

Documentation study Documentation studies are carried out by collecting data related to the identification of needs such as the curriculum used in the current training, what learning resources are available for use in training, what facilities can be accessed by trainees in training activities that have been 
implemented so far. In the documentation study carried out, the researcher collected report data on the implementation of training activities to examine exhaust emissions during 2018-completed.

In this study, interviews were conducted to obtain data on the gap between ideal conditions and actual conditions in the field. The results of the interview with the participants in the exhaust emission examination training, obtained information from the training participants that the teaching materials obtained were still in the form of handouts, the learning time in class was very lacking because all the materials were only given in one day, out of three days of implementing the training activities.

The characteristics of the exhaust emission examination training curriculum are competency-based, the curriculum is a number of training subjects and activities and everything that affects the personal formation of students according to the training objectives. One of the factors that influence the success in the learning process is the use of instructional media. The meaning of hypercontent stems from hypertext, hyperlinks, and hypermedia. Research conducted by (Rocha \& Pereira, 2017) that the concept of hyperlinks contains the concept of hypermedia, which is widely used in content on the Web, making it possible to synchronize, structure, and navigate content that is integrated in video or voice calls. Selfstudy modules that include features such as instructor-narrated videos are an important component of the module as they help to re-create the experience firsthand (Thompson \& Jr, 2016). According to (Mah, 2019) the basic links in HTML serve as hypertext links for users to access specific locations on web pages and work with all technologies and platforms.

Research conducted by (Simon et al., 2015) said that hypermedia learning resources contribute to a richer learning experience. Using hypertext media can improve learning outcomes. There is little research in Indonesia on hypercontent. Researched by (Prawiradilaga, et al., 2017) shows that a new approach in developing hypercontent modules, directs module design that is enriched by learning resources in cyberspace, how by creating links to website pages, YouTube channels, and others via URLs, QR codes, and the like. The next research was conducted by (Siang et al., 2019) aims to produce hypercontent teaching materials for prospective primary guides in the Adventist church, which can be used for self-study using the Rowntree development model. (Winarsih, 2019) conducted a research aims to develop hypercontent learning modules for students from 3T regions at STKIP Surya Tangerang. This study is a Research and Development (R\&D) research using Derek Rowntree's model. And further research with the title "Module Development Based on Hypercontent Material Basic Principles of Making 2D Animation Subjects 2D and 3D Animation for Class XI Multimedia at SMK Muhammadiyah 2 Taman." (Hidayat \& Rusijono, 2020). This study aims to produce and find out the benefits of a Hypercontent-based module, the basic principles of making 2D animation in 2D and 3D animation subjects in improving learning outcomes of class XI Multimedia students at SMK Muhammadiyah 2 Taman, using the ADDIE model.

From the results of the literature search that has been discussed above, it is concluded that printed learning resource materials, by utilization learning resources, and hypercontent learning materials enrich learning with learning resources from cyberspace and improve student learning outcomes, but have not measured the character of students. Some studies use QR Code media but these studies lead customers to the website to be used as a learning resource for students. The learning process that uses hyperlinks, hypermedia, video tutorials, QR codes, modules, and web / online learning makes it easier for teachers when teaching and can improve participant understanding so that participant learning outcomes improve. Meanwhile, the research that I did was to produce learning materials for training, especially training at the Ministry of Transportation, following the advancement of motorized vehicle technology which has developed rapidly.

From the results of the research that has been done, it can be seen that the hypercontent module is effective in terms of learning, there is a need for a hypercontent module because the print module has limitations in the delivery of the visual aspects, therefore there is a need for hypercontent that provides visual aspects to participants with links in the form of videos, QR codes, youtube , hyperlinks, hypermedia, hypertext, and cloud computing, as an effort to help facilitate training activities so that they have a positive impact, especially in creating an effective, efficient, factual and interesting learning process so that trainees gain maximum knowledge, skills and attitudes. The hypercontent module for examining exhaust gas emissions will be made using a product-oriented development model, namely the Rowntree model.

Based on the results of the study, it can be concluded that the participants in the exhaust emission examination training gave positive opinions about the development of the exhaust emission inspection module, because the module is an independent and conventional learning material that is made and arranged systematically and completely, which students use to achieve learning objectives. 


\section{Conclusion}

Based on the research results, the following conclusions can be made the characteristics of the training participants are from the age of 22 to 45 years, including adult students who can learn independently for the benefit of work and profession which they consider important for career sustainability as well as family future, the teaching materials provided were in the form of handouts, the time for providing the material is very short, so it is necessary to develop a module as an independent study material for trainees to examine exhaust gas emissions. With the development of modules, it is possible to improve the understanding and learning outcomes of trainees in studying exhaust emissions from vehicles when compared to conventional learning. Suggestions that can be proposed based on the results of the needs analysis, it is necessary to develop a module for examining exhaust emissions for independent learning by training participants. Module development with a hypercontent approach is recommended, because the print module has limitations in the delivery of the visual aspects, therefore it is necessary to have a hyper content that provides a visual aspect to participants with links in the form of video, QR Code, youtube, hyperlink, hypermedia, hypertext, and cloud computing, as efforts to help facilitate training activities so that they have a positive impact, especially in creating a learning process that is effective, efficient, factual and interesting so that training participants gain maximum knowledge, skills and attitudes. The hypercontent module for examining exhaust gas emissions will be made using a product-oriented development model, namely the Rowntree model.

\section{Acknowledgement}

We would like to thank the Indonesian Land Transportation Police (PTDI) STTD - Bekasi for giving researchers the opportunity to conduct research.

\section{References}

Amin M, Muslim Suyitno, Wirasti Murti K (2019). Pengembangan Modul Pembelajaran Hypercontent Pengenalan Perangkat Jaringan Komputer Untuk Mahasiswa Asal Daerah 3T. 1(1), 199-204.

Borck, R. (2019). Public transport and urban pollution it. Regional Science and Urban Economics, 77(November 2018), 356-366. https://doi.org/10.1016/j.regsciurbeco.2019.06.005

Cetin, M. (2015). The Role of the Chemical Sciences Training on the Emission Control Systems in Vehicles. Education Journal, 4(1), 20. https://doi.org/10.11648/j.edu.20150401.15

Gunawan, S., Hasan, H., Dini, R., \& Lubis, W. (2020). Pemanfaatan Adsorben dari Tongkol Jagung sebagai Karbon Aktif untuk Mengurangi Emisi Gas Buang Kendaraan Bermotor. 3(1), 38-47.

Hakim, L., Sitorus, Z., Muzakky, M., \& Maududy, A. (2018). Design tool of Motor Vehicle Emissions Measurement Devices with Based on Arduino Nano with Android Smartphone Viewer. 13(6), 39753978.

Hidayat Moch. Rizky dan Rusijono. (2020). Pembuatan Animasi 2d Mata Pelajaran Animasi 2d Dan 3d Kelas Xi Multimedia Di Smk Muhammadiyah 2 Taman Moh . Rizqi Hidayat. Teknologi Pendidikan, Fakultas Ilmu Pendidikan, Universitas Negeri Surabaya.

Huang, J., Deng, F., Wu, S., Zhao, Y., Shima, M., Guo, B., ... Guo, X. (2016). Acute effects on pulmonary function in young healthy adults exposed to traffic-related air pollution in semi-closed transport hub in Beijing. Environmental Health and Preventive Medicine, 21(5), 312-320. https://doi.org/10.1007/s12199-016-0531-5

Januszewski A. and Molenda M. (2008). Educational Technology. London: Lawrence Erlbaum Associates.

Kusumaningsih, E., Nadiroh, N., \& Ibrahim, N. (2019). Module Achievement of 1st Piano Minor Learning Standard Competence Based on Multimedia at the Jakarta Institute of Art. 343(Icas), 199-203. https://doi.org/10.2991/icas-19.2019.41

L., S. J., Ibrahim Nurdin, \& Rusmono. (2017). Pengembangan Paket Modul Cetak Mata Pelajaran Pendidikan Agama Kristen SMP Negeri Tidore Kepulauan. Jurnal Teknologi Pendidikan, 19(3), 191205.

Lau, S. B., Lee, C., \& Prasad, Y. (2015). A folksonomy-based lightweight resource annotation metadata schema for personalized hypermedia learning resource delivery. 23(1), 79-105.

Mah, B. Y. (2019). Journal of English Language Teaching A Review on the Application of Blog, Blogger , Widget and Hypertext to Develop a Web-Based Instructional Tool. 54-58. https://doi.org/10.26418/jeltim.v1i2.31505 
Manurung, S. R. (2016). Improving the Conceptual Understanding in Kinematics Subject Matter with Hypertext Media Learning and Formal Thinking Ability. 7(9), 91-98.

Miarso, Y. (2016). Menyemai Benih Teknologi Pendidikan. Jakarta: Pranada Media Group.

Muziansyah, D. (2015). Model Emisi Gas Buangan Kendaraan Bermotor Akibat Aktivitas Transportasi ( Studi Kasus: Terminal Pasar Bawah Ramayana Koita Bandar Lampung ) Terminal Pasar Bawah Ramayana yang berada di pusat Kota Bandar Lampung Emisi Gas Buang Kendaraan Bermotor Akibat Aktivitas Transportasi "dengan studi kasus. 3(1), 57-70.

Nasir, A. R., \& Bargstädt, H. J. (2017). An Approach to Develop Video Tutorials for Construction Tasks. Procedia Engineering, 196(June), 1088-1097. https://doi.org/10.1016/j.proeng.2017.08.066

Nurdjanah Nunuj. (2015). Emisi CO2 Akibat Kendaraan Bermotor Di Kota Denpasar CO2 Emissions From Vehicle In Denpasar. Jurnal Penelitian Transportasi Darat, 5(1), 1-14. https://doi.org/10.1016/j.jbankfin.2017.09.006

Perhubungan, K. (2018). Peraturan Menteri Perhubungan Republik Indonesia Nomor PM 63 Tahun 2018 tentang Perubahan atas Peraturan Menteri Perhubungan Nomor KM 84 Tahun 2009 tentang Tata Cara Pemberian Bantuan Pendidikan dan Pelatihan Serta Beasiswa di Bidang Transportasi.

Prawiradilaga, D. S. (2016). Wawasan Teknologi Pendidikan. Jakarta: Prenada Media Group.

Prawiradilaga, D. S., Widyaningrum, R., \& Ariani, D. (2017). Prinsip-Prinsip Dasar Pengembangan Modul Berpendekatan Hypercontent. Indonesian Journal of Curriculum and Educational Technology Studies, 5(2), 57-65. https://doi.org/10.15294/ijcets.v5i2.17098

Purwanto, Rahardi A., L. S. (2007). Pengembangan Modul. Depdiknas: Pustekom.

Rocha, H., Ricardo, P., \& Pereira, L. (2017). Hyper-linked Communications : WebRTC enabled asynchronous collaboration. 0-6.

Rowntree, D. (1994). Preparing Materials for Open, Distance and Flexible Learning An Action Guide for Teachers and Trainers. London: Kogan Page Limited.

Sabi, H. M., Uzoka, F. E., Langmia, K., \& Njeh, F. N. (2016). Conceptualizing a model for adoption of cloud computing in education. International Journal of Information Management, 36(2), 183-191. https://doi.org/10.1016/j.ijinfomgt.2015.11.010

Siang J. L, Ibrahim Nurdin, \& Situmorang Robinson. (2019). Development of hypercontent module using jonnuro model learning desain for candidates master guide. International Journal of Recent Technology and Engineering, $8(2$ Special Issue 9), 70-78. https://doi.org/10.35940/ijrte.B1016.0982S919

Siddiquah, A., \& Salim, Z. (2017). The ICT facilities, skills, usage, and the problems faced by the students of higher education. Eurasia Journal of Mathematics, Science and Technology Education, 13(8), 49874994. https://doi.org/10.12973/eurasia.2017.00977a

Situmorang, R., Lagun, J., Ibrahim, N., \& Lagunsiang, J. (2019). Development of Collaborative Learning Materials Based on QR Code to Facilitate Learning. 8(6), 85-98.

Smaldino, Sharon E., Lowther, Deborah L., Russel, J. D. . (2012). Instuctional Technology and Media for Learning (Ninth Editon). New Jersey: Pearson Education Inc.

Sugiyono. (2012). Metode Penelitian Kuantitatif, Kualitatif, dan R \& D. Bandung: Alfabeta.

Suparman, M. A. (2014). Desain Instruksional Modern. Jakarta: Erlangga.

Thompson, A. R., \& Jr, D. J. L. (2016). An Evaluation of Outcomes Following the Replacement of Traditional Histology Laboratories with Self-Study Modules Changes in Technology. 0. https://doi.org/10.1002/ase.1659

Unless, R., Act, P., Rose, W., If, T., \& Rose, W. (2016). Reflective Experiential Learning: Using Active Video Watching for Soft Skills Training.

Zhao, T., \& Qin, J. (2017). Study on Hypertext Reading in Students' Autonomous Learning. Journal of Language Teaching and Research, 8(1), 157. https://doi.org/10.17507/jltr.0801.19 